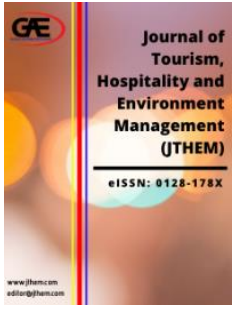

\author{
JOURNAL OF TOURISM, \\ HOSPITALITY AND \\ ENVIRONMENT MANAGEMENT \\ (JTHEM) \\ www.jthem.com
}

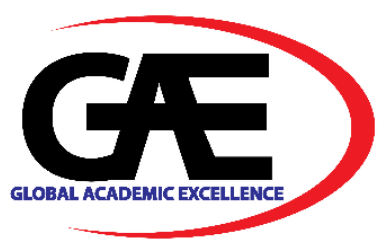

\title{
THE INFLUENCE OF ECONOMIC CAPITAL TOWARDS THE SOCIOECONOMIC BACKGROUND OF THE RURAL COMMUNITY
}

\author{
Nurfasihah Mohd Razali ${ }^{1 *}$, Muhamad Fadhli Rashid ${ }^{2}$ \\ 1 Urban Regional Planning Program, Faculty of Built Environment and Surveying, Universiti Teknologi Malaysia \\ (UTM), Johor, Malaysia \\ Email: nurfasihah795@gmail.com \\ 2 Urban Regional Planning Program, Faculty of Built Environment and Surveying, Universiti Teknologi Malaysia \\ (UTM), Johor, Malaysia \\ Email: m.fadhli@utm.my \\ * Corresponding Author
}

\section{Article Info:}

Article history:

Received date: 01.10 .2021

Revised date: 01.11.2021

Accepted date: 15.11 .2021

Published date: 01.12.2021

\section{To cite this document:}

Razali M. N., \& Rashid, M. F. (2021). The Influence of Economic Capital Towards the Socioeconomic Background of the Rural Community. Journal of Tourism Hospitality and Environment Management, 6 (26), 274-280.

DOI: 10.35631/JTHEM.626025.

This work is licensed under CC BY 4.0

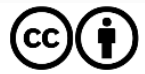

\section{Abstract:}

A rural community is very important in planning for rural development and it cannot be disregard as the rural area is part and parcel of the nation's development. In countries with emerging and developing economies like Malaysia, rural communities constitute the majority of populations where the majority of them are generally poorer and more disadvantaged compared to their urban counterparts. In Malaysia, rural communities have diverse and different levels of socioeconomic backgrounds that are based on the type of settlement, type of economic sector, and rural density level. Therefore, this paper aims to identify the factor of economic capital influencing the socioeconomic background of rural communities. Besides that, this paper also explains the theoretical perspective such as the regional economic growth theory which directly contributed to providing understanding on the factor of economic capital and its indicator influencing the different levels of the socioeconomic background of rural communities. The finding of this paper will provide a preliminary framework for the factor and indicator of economic capital that influenced the socio-economic background of the rural community in the context of Malaysia based on a literature review of previous related research on this topic.

Keywords

Economic Capital, Socioeconomic Background, Rural Community 


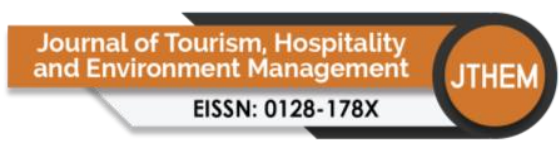

Volume 6 Issue 26 (December 2021) PP. 274-280

DOI 10/35631/JTHEM.626025

\section{Introduction}

The most important view in development of rural economic is the natural resources based development. In most rural areas, several small economic activities which based on natural resources are tended to focussed more on the agriculture, livestock, forestry, fisheries and local tourism (Edirin, 2018; Rashid et al., 2019a). These activities are contributed to the differences of socioeconomic backgrounds where it was conducted by the local community lived in rural areas as they aimed in creating sources of income for their families and to the community members inside their locality (Khairnar et al., 2017; Vorobyov and Bugai, 2019; Rashid et al., 2019b).

In identifying the differences of socioeconomic background of rural community, there are several major factors behind this mosaic situation such as type of occupation and income level (Agarwalet al., 2009; Sánchez-Zamora et al., 2014; Straka and Tuzová, 2016; Rashid et al., 2019a). However, in the context of Malaysia, there are hidden factors that could lead to the differences of socioeconomic background of rural community which directly involved by the endogenous factors (internal) and exogenous factors (external).

Both endogenous and exogenous factors in explaining the economic growth is much highlighted in the territorial innovation model inside the regional economic growth theory. According to Rashid et al. (2019a), the differentiation of economic performance in rural areas is much associated and highly impacted by the economic capital. Therefore, this paper aims to identify the factors of economic capital influencing the differences of socioeconomic background of the rural community.

\section{Theoretical Perspective in Regional Economic Growth}

In regional economic growth, theories are categorized into four major categories, such as traditional models, the pure agglomeration model, local milieu models, and the territorial innovation model (Rashid et al., 2019a). The regional economic growth theories are significant in explaining the theory of economic capitals and their influences on the socioeconomic background. Territorial innovation model is the suitable selection of theory in regional economic growth theories where it's explained on the endogenous and exogenous factors of the economic capital in rural areas which could determine the socioeconomic background of rural community (Terluin, 2003; Agarwal et al., 2009; Rashid et al., 2019b).

According to Terluin and Post (2000); Murdoch (2000); Peet and Hartwick (2015), exogenous factors are defined as an approach to economic development that focuses primarily on external factors that contribute to capital and labour resources, such as capital investment and assistances for government and private entity as well as government policies.

Besides that, the endogenous factor refers to local growth that is predominantly driven by local impulses and is mostly based on local resources (Picchi, 1994; Agarwal et al., 2009; Rashid et al., 2019b). Understanding the territorial innovation model in the regional economic growth theory could conclude that both endogenous and exogenous factors has directly contributed in understanding the factors of economic capital and its indicators influencing the different levels of the socioeconomic background of the rural community. 


\section{Factor of Economic Capital in Rural Community}

The current image of rural communities can be viewed as a "new situation of rural communities" in term of socioeconomic performance based such as good, moderate, and low (Rashid et al., 2019a). This situation raises questions about the factors drives this kind of trend situations. In explaining the factors of economic capital, the method used is by identifying literatures and previous research related to this topic.

Furthermore, this economic capital demonstrates the internal and external factors that are part of the theory of economic growth and directly contribute to the understanding of economic capital. Thus, this paper able to summarise and integrate the identified factors and indicators of economic capital which can be used as method to measure and explain the differences of socioeconomic background of rural community (Table 1).

\section{Table 1: Identification of Factor and Indicator in Economic Capital}

\begin{tabular}{|c|c|c|}
\hline Factor & Indicator & Reference \\
\hline \multicolumn{3}{|c|}{ Endogenous Factor (Internal) } \\
\hline \multirow[t]{3}{*}{$\begin{array}{l}\text { Occupations and } \\
\text { Income }\end{array}$} & Level of income every year & $\begin{array}{l}\text { Agarwal et al. (2009); Sánchez-Zamora et } \\
\text { al. (2014); Straka and Tuzová (2016); } \\
\text { Rashid et al. (2019a) }\end{array}$ \\
\hline & Stability in occupation & $\begin{array}{l}\text { Terluin (2003); Courtney and Moseley } \\
\text { (2008); Sánchez-Zamora et al. (2014); } \\
\text { Straka and Tuzová (2016); Rashid et al. } \\
\text { (2019a) }\end{array}$ \\
\hline & Additional source of income & $\begin{array}{l}\text { Courtney and Moseley (2008); Straka and } \\
\text { Tuzová (2016);Rashid et al. (2019a) }\end{array}$ \\
\hline $\begin{array}{l}\text { People Employed } \\
\text { in Household }\end{array}$ & Balanced job and salary & $\begin{array}{l}\text { Sánchez-Zamora et al. (2014); Straka and } \\
\text { Tuzová (2016); Rashid et al. (2019a) }\end{array}$ \\
\hline $\begin{array}{l}\text { Property and } \\
\text { Asset Ownership }\end{array}$ & Generated cultivated land & $\begin{array}{l}\text { Courtney and Moseley (2008); Klok (2011); } \\
\text { Roberts and Townsend (2016); Rashid et al. } \\
(2019 \mathrm{a})\end{array}$ \\
\hline \multicolumn{3}{|c|}{ Exogenous Factor (External) } \\
\hline Money Transfer & $\begin{array}{l}\text { Money transfer by family } \\
\text { members }\end{array}$ & $\begin{array}{l}\text { Bryden } \text { et al. (2004); Roberts and Townsend } \\
\text { (2016); Rashid } \text { et al. (2019a) }\end{array}$ \\
\hline \multirow[t]{2}{*}{$\begin{array}{l}\text { Government and } \\
\text { Private Sectors } \\
\text { Assistance }\end{array}$} & $\begin{array}{l}\text { Financial and welfare } \\
\text { assistance }\end{array}$ & $\begin{array}{l}\text { Agarwal et al. (2009); Klok (2011); } \\
\text { Sánchez-Zamora et al. (2014); Rashid et al. } \\
\text { (2019a) }\end{array}$ \\
\hline & $\begin{array}{l}\text { Business/ agricultural/ } \\
\text { fishery assistance }\end{array}$ & $\begin{array}{l}\text { Agarwal et al. (2009); Klok (2011); } \\
\text { Sánchez-Zamora et al. (2014); Rashid et al. } \\
\text { (2019a) }\end{array}$ \\
\hline
\end{tabular}

\section{Socioeconomic Background of the Rural Community}

Rural areas in Malaysia have different socioeconomic backgrounds according to the location of the rural areas. The socioeconomic background is represented by the component of social variable which are education and health while economic variable comprises of income and occupation (Bryden et al., 2004; Rathod and Ningshen, 2012; OECD, 2014). Authors like Bollen et al. (2001) and Mustaqim and Islam (2014) defined that the socioeconomic background are important tools to the measure of human development such as individuals or family group of people economic and social position based on education, income, health and 


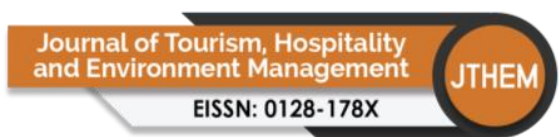

Volume 6 Issue 26 (December 2021) PP. 274-280

DOI 10/35631/JTHEM.626025

occupation. Based on the literature review and previous related paper research, this research will use some variable and indicator related with this research. This paper will summarise the variable and indicator that will measure and use in socioeconomic background in this research (Table 2).

Table 2: Identification of Aspect and Indicator in Socioeconomic Background

\begin{tabular}{|c|c|c|c|}
\hline Component & Variable & Indicator & Reference \\
\hline \multirow[t]{4}{*}{ Social } & \multirow[t]{2}{*}{ Education } & Level of education & $\begin{array}{l}\text { Sirin (2005), OECD (2014), Thomson } \\
\text { (2018), Rathod and Ningshen (2012) }\end{array}$ \\
\hline & & $\begin{array}{l}\text { Home educational } \\
\text { resources }\end{array}$ & $\begin{array}{l}\text { Mustaqim and Islam (2014), Rathod and } \\
\text { Ningshen (2012) }\end{array}$ \\
\hline & \multirow[t]{2}{*}{ Health } & Level of health & $\begin{array}{l}\text { Mustaqim and Islam (2014), Rathod and } \\
\text { Ningshen (2012) }\end{array}$ \\
\hline & & Ability to do work & $\begin{array}{l}\text { Bryden et al. (2004); Roberts and } \\
\text { Townsend (2016); Rashid et al. (2019a) }\end{array}$ \\
\hline \multirow[t]{3}{*}{ Economic } & \multirow[t]{2}{*}{ Income } & Household income & $\begin{array}{l}\text { Bollen et al. (2001), Rathod and } \\
\text { Ningshen (2012), Arsal (2016) }\end{array}$ \\
\hline & & Wealth & $\begin{array}{l}\text { Bollen et al. (2001), Rathod and } \\
\text { Ningshen (2012), Arsal (2016) }\end{array}$ \\
\hline & Occupation & Work Status & $\begin{array}{l}\text { Sirin (2005), Mustaqim and Islam } \\
\text { (2014), Rathod and Ningshen (2012) }\end{array}$ \\
\hline
\end{tabular}

\section{Preliminary Framework of Economic Capital Influencing the Socioeconomic Background of Rural Community}

This research is able to identify the factors and indicators of economic capital as well as the components and variables in the socioeconomic background of the rural community based on the literature and previous studies related to this research. For the factors and indicators of economic capital related to the economy in rural areas are influenced by the socioeconomic background, which indicates the economic and social environment, which can highlight the various socioeconomic patterns in each rural area in Malaysia.

To understand the economic capital and socioeconomic background of rural communities the preliminary framework is provided to use in this paper. In the socioeconomic background is divided into component such as economic and social. In economic, income and occupation such as level of income, stability in occupation, and additional source income were identified as economic background. These identified factors can lead into differences in socioeconomic background of rural communities in term of the household income and wealth level.

In social, education and health were identified as these variables were important in investigating social background of rural community. In rural community, education is one of important action for rural community to change their socioeconomic background with proper education for their family members as it could guarantee a suitable job and balanced income. Therefore, this study can triangulate the understanding of the rural community's socioeconomic background, which includes income, occupation, education, and health, based on the five (5) factors and eight (8) indicators of economic capital highlighted in Figure 1. 


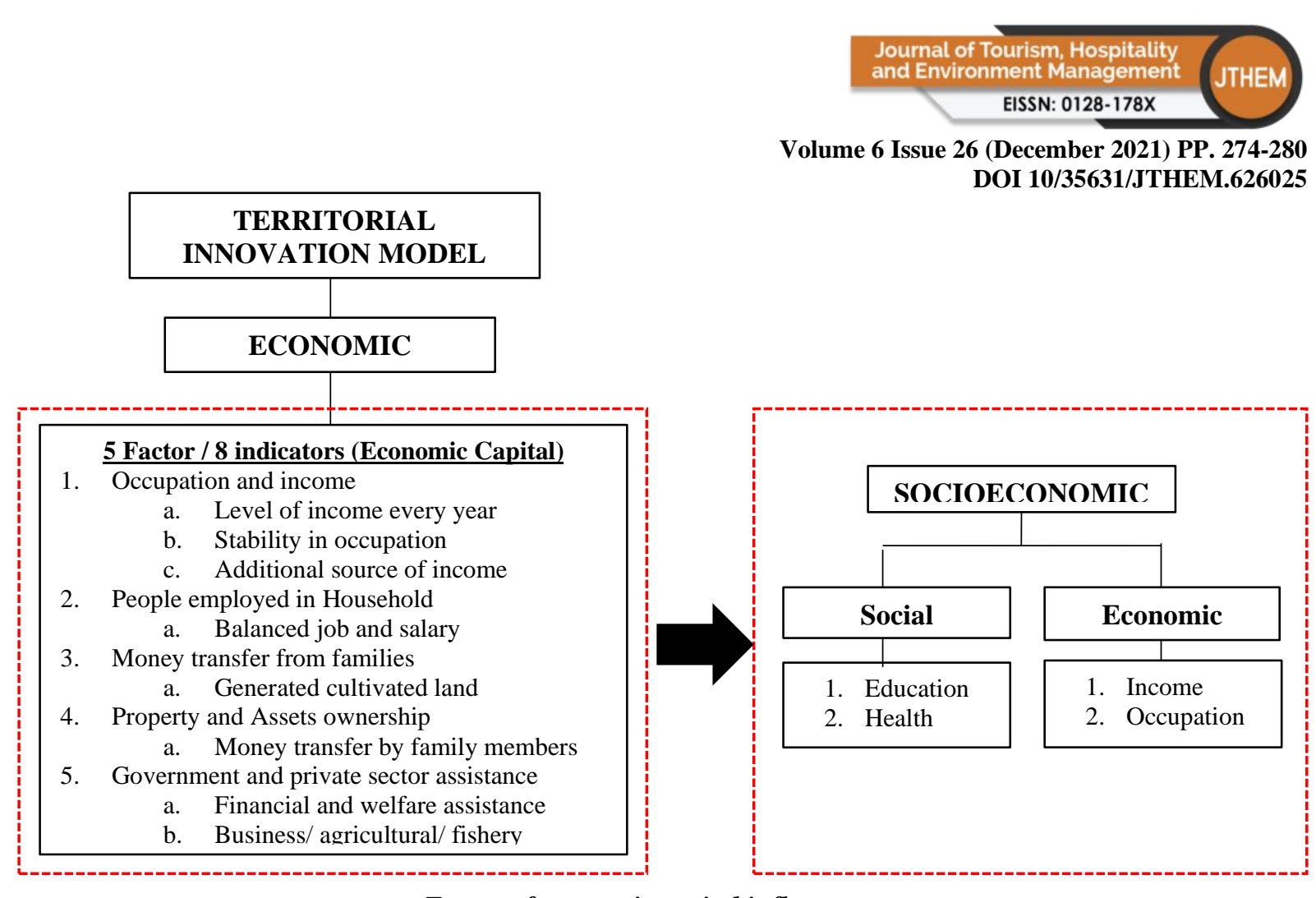

Factor of economic capital influence socioeconomic background of rural

Figure 1: Theoretical Framework of Economic Capital and Socioeconomic Background in Rural Communities

\section{Conclusion}

The key finding of this paper is able to provide theoretical framework that incorporated between economic capital and socioeconomic background of rural communities. There are five (5) factors and eight (8) indicators of the economic capital were identified and integrated into the theoretical framework of economic capital and socioeconomic background in rural communities.

With this theoretical framework, it can serve as a measuring tool in analysing the differences of socioeconomic background of the rural community that involved four (4) variables such as income, occupation, education and health. Besides that, this framework also able to analyse the socioeconomic background in rural community with the different pattern economic background of rural areas. Therefore, this framework could be a useful tool to solve the issue of differences of socioeconomic background of the rural community which connected to the main issue of the rural decline.

\section{Acknowledgement}

The authors would like to acknowledge appreciation for the support of the sponsors from Universiti Teknologi Malaysia for this project - Interpreting Differentiation of Village Economic Performance in Rural Areas in Johor (Project No. PY/2020/04067).

\section{References}

Agarwal, S., Rahman, S. and Errington, A. (2009). Measuring the determinants of relative economic performance of rural areas. Journal of Rural Studies, 25(3), 309-321.

Bryden, J.M., Courtney, P., Atterton, J. and Timm, A. (2004). Scotland - North and South. Why Local Economies Differ: The Dynamics of Rural Areas in Europe. London: Edwin-Mellen Press. 


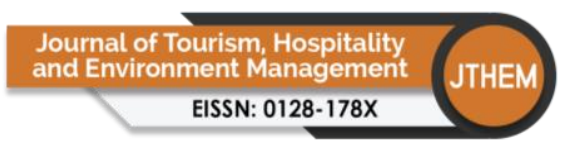

Volume 6 Issue 26 (December 2021) PP. 274-280 DOI 10/35631/JTHEM.626025

Bollen, A.K., Glanville, L.J., and Stecklov G. (2001), Socio-Economic Status and Class in Studies of Fertility and Health in Developing Countries, Annu. Rev. Sociol, 27, pp. 153-185

Courtney, P. and Moseley, M. (2008). Determinants of Local Economic Performance: Experience from Rural England. Local Economy, 23(4), 305-318.

Edirin, E.A. (2018). Opportunities and challenges of economic development in Malaysia's rural areas. Trends in Undergraduate Research, 1(1), h1-5.

Khairnar, M.R., Wadgave, U., and Shimpi, P.V. (2017). Kuppuswamy's socio-economic status scale: a revision of occupation and income criteria for 2016. The Indian Journal of Pediatrics, 84(1), 3-6.

Klok, N. (2011). The detection of main factors that influence on the development of rural tourism. Socio-economic Research Bulletin, 41,37-40.

Mustaqim, M., and Islam, M. (2014), Demographic and Socio-Economic Characteristics of Inhabitants of Udaypur Village, Malda District, West Bengal, Indian Streams Research Journal, Vol. 4, Issue I, pp. 1-13.

Murdoch, J. (2000). Networks-A New Paradigm of Rural Development. Journal of Rural Studies, 16(4), 407-419.

Organisation for Economic Cooperation and Development (OECD) (2014). Improving Social Inclusion at the Local Level through the Social Economy: Designing an Enabling Policy Framework. OECD Publishing.

Peet, R. and Hartwick, E. (2015). Theories of Development: Contentions, Arguments, Alternatives. New York: Guilford Publications.

Picchi, A. (1994). The Relations between Central and Local Powers as Context for Endogenous Development. In: Ploe g, J.D. van der, Long, A. (Eds.), Born from within; Practice and Perspectives of Endogenous Rural Development. Van Gorcum, Assen, 195-203.

Rashid, M.F., Ngah, I., and Misnan, S.H. (2019a). Framework for economic performance of rural areas in Malaysia: A territorial approach. International Journal of Built Environment and Sustainability, 6(1-2), 1-6.

Rashid, M.F., Ngah, I., and Misnan, S.H. (2019b). Revitalizing Rural Areas in Malaysia: A Framework for Economic Revitalization. In IOP Conference Series: Earth and Environmental Science (Vol. 385, No. 1, p. 012004). IOP Publishing.

Rathod, G.R., and Ningshen, A., (2012), Measuring the Socio-Economic Status of Urban below Poverty Line Families in Imphal City, Manipur: A Livelihoods Study, International Journal of Marketing, Financial Services and Management Research, Vol. 1(12), pp. 62-69

Roberts, E. and Townsend, L. (2016). The Contribution of the Creative Economy to the Resilience of Rural Communities: Exploring Cultural and Digital Capital. Sociologia Ruralis, 56(2), 197-219.

Sánchez-Zamora, P., Gallardo-Cobos, R., and Ceña-Delgado, F. (2014). Rural areas face the economic crisis: Analyzing the determinants of successful territorial dynamics. Journal of Rural Studies, 35, 11-25

Straka, J., and Tuzová, M. (2016). Factors affecting development of rural areas in the Czech Republic: A literature review. Procedia-Social and Behavioral Sciences, 220, 496-505.

Sirin, S.R. (2005). Socioeconomic status and academic achievement: A meta-analytic review of research. Review of educational research, 75(3), 417-453.

Terluin, I.J. and Post, J.H. (2000). Employment Dynamics in Rural Europe. New York: CABI Publishing. 
Terluin, I.J. (2003). Differences in Economic Development in Rural Regions of Advanced Countries: An Overview and Critical Analysis of Theories. Journal of Rural Studies, 19, 327-344.

Vorobyov, S., and Bugai, Y. (2019). Factors of socio-economic development of rural areas. In IOP Conference Series: Earth and Environmental Science (Vol. 395, No. 1, p. 012109). IOP Publishing. 